This is the author's manuscript of the presented paper. The publisher-formatted version may be available through the publisher's web site or your institution's library

\title{
The practice and profession of horticultural therapy in the United States
}

\author{
C. A. Shoemaker, Elizabeth R. Messer Diehl
}

\section{How to cite this paper}

If you make reference to this version of the manuscript, use the following information:

Shoemaker, C. A., \& Diehl, E. R. M. (2010). The practice and profession of horticultural therapy in the United States. Retrieved from http://krex.ksu.edu

\section{Published Version Information}

\section{Citation:}

Shoemaker, C. A., \& Diehl, E. R. M. (2010). The practice and profession of horticultural therapy in the United States. In S. N. Goodyear, \& C. A. Shoemaker (Eds.), Acta Horticulturae: Vol. 954. Proceedings of the Xth International People-Plant Symposium on Digging Deeper: Approaches to Research in Horticultural Therapy and Therapeutic Horticulture (pp. 161-163). Leuven: ISHS.

Copyright: () ISHS

Digital Object Identifier (DOI):

Publisher's Link: http://www.actahort.org/books/954/

This item was retrieved from the K-State Research Exchange (K-REx), the institutional repository of Kansas State University. K-REx is available at http://krex.ksu.edu 


\title{
The Practice and Profession of Horticultural Therapy in the United States
}

C.A. Shoemaker

Department of Horticulture, Forestry and

Recreation Resources

Kansas State University

Manhattan, KS

United States
Elizabeth R. Messer Diehl

Terra Firma Design, Inc.

Gainesville, FL

United States

Keywords: horticultural therapy education, American Horticultural Therapy Association, People Plant Council, work settings

\begin{abstract}
While reference to the health benefits of plants and gardening can be found in the early days of the United States, the beginnings of the profession of horticultural therapy came after the conclusion of World War II, as a result of the significant growth in occupational therapy programs and rehabilitation medicine. This paper will present brief reviews of the history of the profession, current educational opportunities, and common work settings of those that practice horticultural therapy.
\end{abstract}

\section{INTRODUCTION}

Historically, the use of horticulture in institutional settings has included having patients as field labor in farm settings (Tereshkovich, 1975), providing diversions for long-term patients (McDonald, 1995), enhancing educational programs for mentally handicapped children (Lawrence, 1900), and as a rehabilitative component to war veterans (Lewis, 1976).

In the United States, the significant growth of occupational therapy (OT) programs in Veteran Hospitals at the conclusion of World War II was really the impetus for the beginnings of the profession of horticultural therapy. Many OT text books through the 1940s would include chapters on the use of horticulture and plants and the first efforts to distinguish horticultural therapy as a separate treatment modality were by occupational therapists.

In 1973, the National Council for Therapy and Rehabilitation through Horticulture was formed to promote and enhance the profession as a therapeutic intervention and rehabilitative medium. Annual conferences began that same year. Professional registration was established in 1975 and a core curriculum was approved in 1985. In 1987 it became the American Horticultural Therapy Association (AHTA). The Journal of Therapeutic Horticulture, the professional publication of AHTA, has been produced since 1986.

This paper will present the current status of the profession of horticultural therapy in the United States as it is expressed through educational opportunities, associations, and work settings of horticultural therapy practitioners.

\section{EDUCATION}

Horticultural therapy instruction is offered through a variety of educational settings including universities and colleges, public gardens, independent institutes and hospitals. At the university level, programs are offered through horticulture departments thus students earn a degree in horticulture with a specialization, concentration or option in horticultural therapy. At 
the time of this writing there are four universities offering an option in horticultural therapy at the undergraduate level. These programs include 10-12 credits of course work specifically in horticultural therapy. Some of these universities also offer these courses as a certificate program while other universities offer a certificate program only. In addition to degree and certificate programs, there are several (around 10) colleges and universities that offer one or two classes in horticultural therapy. (Visit http://www.ahta.org/content.cfm?id=colleges for more information).

Many public gardens have horticultural therapy programs serving varied client groups at the gardens as well in the community they are located in. Some have expanded their services to provide professional training through conferences, shadowing programs, and certificate programs. A requirement for the voluntary professional registration program through AHTA is that all coursework must be for college credit, thus gardens are now partnering with colleges or universities to offer their certificate programs. There is one private institute and one health system offering certificate programs in partnership with a university.

\section{ASSOCIATIONS}

The American Horticultural Therapy Association is the only national association dedicated to promoting and advancing the profession of horticultural therapy. The goals of AHTA are: "To develop the resources and relationships needed to carry out our mission and vision; To be the best source of information about the benefits of horticultural therapy; To be an effective organization, responsive to members, supporters and the public; and Describe and promote high standards of practice" (www.ahta.org/content.cfm?id=about). AHTA addresses these goals through administering a voluntary professional registration program; offering memberships to individuals, students, professionals, and institutions; publishing a bi-annual journal and a quarterly newsmagazine; and offering an annual conference. In 2007 AHTA published a definitions and positions paper that provided specific definitions for horticultural therapy and therapeutic horticulture as well as other important terms used in the profession (this paper can be accessed from www.ahta.org).

Primarily through the efforts of a few academics and researchers in the early 1990s, there are several professional associations today that offer something related to horticultural therapy within the context of their membership. For example, the American Society for Horticultural Science has a working group called human issues in horticulture. The purpose of this group is to stimulate discussion among those engaged in research and education programs in areas of horticulture that interact with the social sciences, such as psychology, education, various forms of therapy, urban and rural sociology, and urban and rural development. Other examples are the People-Plant Interaction Section of the American Public Gardens Association (http://www.publicgardens.org/content/people-plant-interaction) and the Healthcare and Therapeutic Design Professional Practice Network of the American Society of Landscape Architects (http://www.asla.org/PPNIndividualHome.aspx?id=3308).

The People Plant Council is an international group of various individuals and professions with the purpose to document and communicate the effect that plants have on human well-being and improved life-quality. The primary vehicle to accomplish this is through the coordination of a biennial international people plant symposium and the publication of the proceedings of each symposium (www.peopleplantcouncil.org).

\section{WORK SETTINGS}


Horticultural therapy and therapeutic horticulture programs are offered in a myriad of settings serving a variety of population groups. Results of a survey of horticultural therapy practitioners registered with AHTA in 2001 indicated vocational training centers as the most reported setting (Shoemaker, 2002). Other settings mentioned were nursing homes, botanic gardens, and rehabilitation hospitals. A review of the AHTA membership directory indicates that in addition to the above mentioned settings, AHTA members also practice in Veterans Affairs facilities, correctional facilities, and psychiatric care facilities, as well as facilities for individuals with developmental disabilities. While some AHTA members are employed directly by the facility in which they conduct programming, others operate as private practitioners and may conduct programs in several different settings.

AHTA defines horticultural therapy as "the engagement of a person in gardening-related activities, facilitated by a trained therapist, to achieve specific treatment goals" (http://www.ahta.org/content.cfm?id=faq, accessed 04/17/2012). Many horticultural therapy programs in the U.S. would not be considered horticultural therapy under this definition, thus the terms social horticulture, vocational horticulture, therapeutic horticulture, and even terms such a community gardening and children's gardening have been used to explain these broader uses of horticulture and gardening for human well-being. In this context, the settings for practice are expanded to include public and private schools and community and botanic gardens, in addition to the settings mentioned in the previous paragraph.

\section{CONCLUSION}

Many allied health therapies, such as recreational therapy, music therapy, and art therapy, emerged following WWII similar to the horticultural therapy profession. While these related allied therapies have been successful in becoming established professions, horticultural therapy is still referred to as an emerging profession. Continued validation and growth of the horticultural therapy profession is critically needed through universal standards for clinical practice; defining and communicating entry level skills and educational attainment; research evidence that can inform the practice of horticultural therapy; and established collaborations between practitioners, academicians, and research scientists.

\section{Literature Cited}

Lawrence, G.M. 1900. Principles of education for the feeble minded. J Psycho-Aesthenics 4(3): 100-108.

Lewis, C. 1976. The evolution of horticultural therapy in the United States. Presented at the Fourth annual meeting of the National Council for Therapy and Rehabilitation through Horticulture. September 6, Philadelphia, PA.

McDonald, J. 1995. A comparative study of the horticultural therapy professions in the United Kingdom and the United States of America. Master's thesis: University of Reading, England.

Shoemaker, C.A. 2003. An analysis of registered horticultural therapists. J. of Therapeutic Hort.14:50-55.

Tereshkovich, G. 1975. Horticultural therapy: A review. National Council for Therapy and Rehabilitation through Horticulture lecture and publication series, February 1(1), pp. 1-4. 